\title{
PENGARUH PERSEPSI GAYA BELAJAR TERHADAP PRESTASI MAHASISWA GENERASI Z DI PERGURUAN TINGGI
}

\author{
Nur Habibah ${ }^{1}$, Siti Rahmawati ${ }^{2}$, \& Andita Sayekti ${ }^{3}$ \\ e-mail: habibah_020198@apps.ipb.ac.id ${ }^{1}$ \\ Institut Pertanian Bogor \\ Jalan. Raya Dramaga Kampus IPB Dramaga Bogor, Jawa Barat 16680
}

\begin{abstract}
Abstrak: Generasi $\mathrm{Z}$ mendominasi di perguruan tinggi dan memiliki karakteristik yang unik yaitu cepat beradaptasi dengan perkembangan teknologi. Perguruan tinggi merupakan salah satu tempat pembelajaran untuk mempersiapkan sumberdaya manusia yang berkualitas era revolusi industri 4.0. Penelitian ini bertujuan untuk (1) mengidentifikasi karakteristik mahasiswa generasi Z (2) menganalisis pengaruh gaya belajar terhadap prestasi mahasiswa generasi $Z$. Responden pada penelitian ini adalah mahasiswa Departemen Manajemen Fakultas Ekonomi dan Manajemen IPB angkatan 52-55. Metode pengambilan sampel yaitu Nonprobability Sampling dengan teknik Purposive Sampling. Alat analisis yang digunakan adalah analisis deskriptif dan SEM-PLS menggunakan Smart Pls 3.0. Hasil penelitian menunjukkan bahwa karakteristik responden merupakan bagian dari generasi $\mathrm{Z}$ berusia 18-22 tahun dan gaya belajar auditori memengaruhi prestasi secara signifikan.
\end{abstract}

Kata-kata kunci: Generasi Z, gaya belajar, prestasi, SEM-PLS

\section{THE EFFECT OF LEARNING STYLE PERCEPTION TOWARDS THE ACHIEVEMENT OF Z GENERATION STUDENT IN HIGHER EDUCATION}

\begin{abstract}
Generation $\mathrm{Z}$ which known to have a unique characteristic as able to quickly adapt to rapid technological advancement, currently dominates the population of university students. University is one place of learning to prepare people to be qualified human resources in the industrial revolution era 4.0. This study aims to (1) find out the characteristics of Generation $Z$ students, (2) analyze the effect of learning styles on Generation Z student achievement. The respondents of this study were batch 52-55 students of Management Department FEM IPB. The sampling method used in this study was nonprobability purposive sampling. The analytical tool used in this study were descriptive analysis and SEM-PLS using Smart PLS 3.0. The result shows that respondents' characteristics were part of Generation $\mathrm{Z}$ aged 18-22 years and auditory learning style significantly affected student achievement.
\end{abstract}

Keywords: Achievement, generation Z, learning style, SEM-PLS

\section{PENDAHULUAN}

Perkembangan teknologi dan informasi berkembang dengan pesat. Inovasi tercipta seiring dengan berkembangnya teknologi. Hal ini tentunya berdampak pada individu-individu, salah satunya adalah generasi Z. Generasi menurut Mannheim (1923) dalam Moore et. al. (2017) adalah kelompok yang terdiri dari individu yang memiliki kesamaan dalam rentang usia dan mengalami peristiwa sejarah penting dalam suatu periode waktu yang sama. Generasi $\mathrm{Z}$ disebut juga internet generation atau digital native yang lahir di saat teknologi berkembang pesat. Perkembangan teknologi berdampak pada pola perilaku, gaya hidup, cara belajar, dan karakter lainnya. Generasi Z menurut Seemilier dan Grace (2017) adalah generasi yang lahir 
pada tahun 1995-2010. Generasi Z telah dipengaruhi oleh teknologi inovasi yaitu ponsel pintar, internet dengan kecepatan yang tinggi, situs media sosial, belanja online, buku elektronik dan lainnya yang saling terhubung di kehidupan sehari-hari. Menurut Mardiana (2011) dalam Elizabeth (2015) Generasi $\mathrm{Z}$ atau digital native menganggap bahwa teknologi digital sebagai bagian dari kehidupan yang tidak terpisahkan. Terkait perilaku generasi $\mathrm{Z}$ tersebut, tentunya lembaga pendidikan menyadari bahwa saat ini dihadapkan dengan generasi berbeda dari sebelumnya. Dengan demikian perlu adanya perhatian khusus dalam menghadapi generasi $\mathrm{Z}$ ini sehingga dapat meningkatkan potensi-potensi dan membawa ke arah yang lebih positif.

Perguruan tinggi merupakan salah satu tempat pembelajaran untuk mempersiapkan sumberdaya manusia berkualitas era revolusi industri 4.0 di Indonesia. UU No. 20 Tahun 2003 menjelaskan bahwa "Pendidikan adalah usaha sadar dan terencana untuk mewujudkan suasana belajar dan proses pembelajaran agar peserta didik secara aktif mengembangkan potensi dirinya untuk memiliki kekuatan spiritual keagamaan, pengendalian diri, kepribadian, kecerdasan, akhlak mulia, serta keterampilan yang diperlukan dirinya dan masyarakat". Hubungan revolusi industri 4.0 erat kaitannya dengan dunia pendidikan yaitu mengikuti perkembangan teknologi dengan memanfaatkan teknologi dan informasi sebagai fasilitas untuk memperlancar proses pembelajaran. Menurut Lifter dan Tschiener (2013) dalam Kemenristekdikti (2018) prinsip dasar revolusi industri 4.0 adalah menggabungkan mesin, alur kerja, dan sistem dengan menerapkan jaringan cerdas sepanjang rantai dan proses produksi untuk mengendalikan satu sama lain secara mandiri. Perguruan tinggi harus mempersiapkan mahasiswa dalam menghadapi dan bertahan di era revolusi industri 4.0 dimana sistem pendidikan di perguruan tinggi perlu dievaluasi dan mencerminkan kurikulum yang sesuai dengan revolusi industri 4.0 .

Program Sarjana Manajemen, Fakultas Ekonomi dan Manajemen (FEM) Institut Pertanian Bogor (IPB) didirikan pada tahun 2000. Departemen Manajemen memiliki empat bidang peminatan yaitu divisi manajemen sumberdaya manusia, divisi manajemen pemasaran, divisi manajemen keuangan, dan divisi manajemen produksi operasi. Peningkatan sumberdaya manusia yang berkualitas khususnya mahasiswa agar dapat bersaing pada era revolusi industri 4.0, sesuai dengan misi dari Departemen Manajemen yaitu menyelenggarakan pendidikan tinggi standar internasional di bidang manajemen yang berkualitas tinggi menghasilkan lulusan dengan kompetensi manajemen unggul dilengkapi dengan keterampilan komunkasi, berorganisasi, komputasi, dan kewirausahaan. Untuk mengetahui capaian yang telah dilakukan oleh mahasiswa selama proses pembelajaran, maka dapat dilihat pada pencapaian indeks prestasi kumulatif (IPK) dan pecapaian perlombaan yang di ikuti oleh mahasiswa. Indeks prestasi kumulatif merupakan salah satu tolak ukur keberhasilan perguruan tinggi dalam meningkatkan sumberdaya manusia dalam hal ini adalah mahasiswa aktif Departemen Manajemen angkatan 52-55. Berikut rataan IPK mahasiswa Departemen Manajemen dari tahun ajaran 2015/2016 sampai dengan tahun ajaran 2018/2019 pada Gambar 1.

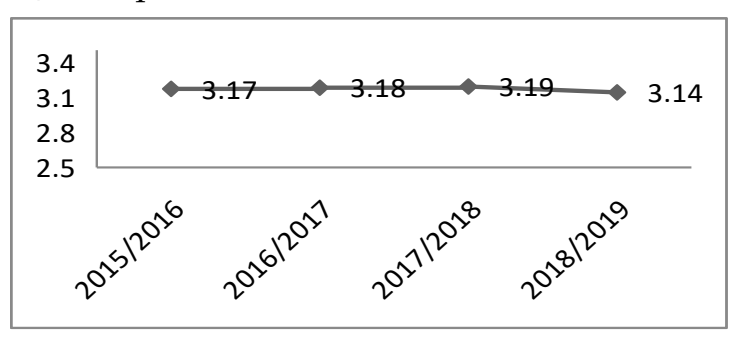

Gambar 1. Grafik Data Rataan IPK Tahun Ajaran 2015/2016-2018/2019

Berdasarkan Gambar 1 rataan indeks prestasi kumulatif mahasiswa Departemen Manajemen berada pada angka 3.00 tahun ajaran 2015/2016 sampai dengan 2018/2019. Namun pada tahun ajaran 2017/2018 sampai dengan 2018/2019 mengalami penurunan. Meskipun tidak mengalami penurunan yang signifikan, namun hal ini menujukkan bahwa prestasi mahasiswa Departemen Manajemen berdasarkan hasil capaian IPK masih termasuk dalam kategori baik yang berada pada rentang IPK >3.00 (Kemenristekdikti 2017). Selain mengetahui rataan IPK mahasiswa Departemen Manajemen, perlu mengetahui rataan IPK $<3.00$ pada tahun ajaran 2015/2016 sampai dengan 2017/2018. Berikut rataan IPK $<3.00$ pada Gambar 2.

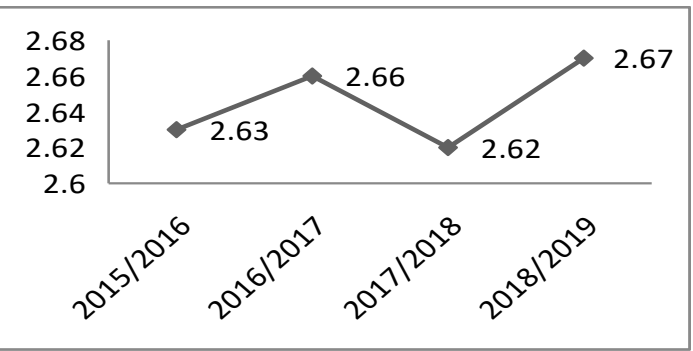

Gambar 2. Grafik Data Rataan IPK kurang dari 3.00 Tahun Ajaran 2015/2016-2018/2019

Berdasarkan Gambar 2 bahwa rataan IPK $<3.00$ 
menunjukkan tren yang fluktuatif setiap tahunnya, maka perlu perhatian khusus kepada mahasiswa yang memiliki IPK $<3.00$ agar dapat meningkatkan prestasi khususnya di bidang akademik. Mengetahui kualitas mahasiswa aktif manajemen, maka dapat diketahui melalui prestasi non akademik berupa angka partisipan murni (APM). APM digunakan untuk mengetahui seberapa banyak mahasiswa memanfaatkan fasilitas pendidikan yang ada (Kemenristekdikti 2017). Selanjutnya prestasi non-akademik mahasiswa aktif Departemen Manajemen dilihat dari angka partisipan murni dapat dilihat pada Tabel 1.

Tabel 1.

APM prestasi non-akademik mahasiswa Departemen Manajemen IPB

\begin{tabular}{|c|c|c|c|c|c|c|}
\hline \multirow{2}{*}{$\begin{array}{l}\text { Tahun } \\
\text { Masuk }\end{array}$} & \multirow{2}{*}{ Populasi } & \multirow{2}{*}{ Kategori } & \multicolumn{3}{|c|}{ Persentase Keikutsertaan } & \multirow{2}{*}{$\begin{array}{l}\text { Rata- } \\
\text { rata } \\
\text { APM }\end{array}$} \\
\hline & & & Lokal & Nasional & Internasional & \\
\hline \multirow{5}{*}{2015} & \multirow{5}{*}{101} & Kompetisi & $10.89 \%$ & $41.58 \%$ & $8.91 \%$ & $20.46 \%$ \\
\hline & & Mobilitas & - & $5.94 \%$ & $20.79 \%$ & $13.37 \%$ \\
\hline & & $\begin{array}{l}\text { Arts and } \\
\text { Culture }\end{array}$ & $5.94 \%$ & - & - & $5.94 \%$ \\
\hline & & Sports & $5.94 \%$ & - & - & $5.94 \%$ \\
\hline & & $\begin{array}{l}\text { Seminar/ } \\
\text { Workshop }\end{array}$ & $100 \%$ & $76.24 \%$ & - & $88.12 \%$ \\
\hline \multirow{5}{*}{2016} & \multirow{5}{*}{111} & Kompetisi & - & $27.93 \%$ & $4.50 \%$ & $16.22 \%$ \\
\hline & & Mobilitas & - & - & $9.01 \%$ & $9.01 \%$ \\
\hline & & $\begin{array}{l}\text { Arts and } \\
\text { Culture }\end{array}$ & $9.01 \%$ & - & - & - \\
\hline & & Sports & $9.91 \%$ & - & - & - \\
\hline & & $\begin{array}{l}\text { Seminar/ } \\
\text { Workshop }\end{array}$ & $100 \%$ & $2.70 \%$ & - & $51.35 \%$ \\
\hline \multirow{5}{*}{2017} & \multirow{5}{*}{127} & Kompetisi & $0.79 \%$ & $30.71 \%$ & - & $15.75 \%$ \\
\hline & & Mobilitas & - & $2.36 \%$ & $4.72 \%$ & $3.54 \%$ \\
\hline & & $\begin{array}{l}\text { Arts and } \\
\text { Culture }\end{array}$ & $7.09 \%$ & - & - & - \\
\hline & & Sports & $7.87 \%$ & - & - & - \\
\hline & & $\begin{array}{l}\text { Seminar/ } \\
\text { Workshop }\end{array}$ & $100 \%$ & $22.83 \%$ & - & $61.42 \%$ \\
\hline
\end{tabular}

Berdasarkan Tabel 1 mahasiswa aktif Departemen Manajemen yang memiliki APM prestasi non-akademik didominasi oleh mahasiswa tahun masuk 2015. Hal ini karena mahasiswa angkatan 52 telah memasuki tingkat akhir dan telah memiliki banyak prestasi dalam hal ini yaitu kompetensi, mobilitas, Arts and Culture, sport, seminar/workshop. Seminar/workshop merupakan prestasi non akademik yang memiliki presentasi terbesar. Hal ini tentunya menjadi tantangan bersama khususnya Departemen Manajemen untuk terus konsisten dalam mendorong mahasiswa agar lebih aktif dalam mengikuti berbagai kegiatan dan perlombaan baik akademik maupun non akademik.

Meningkatkan kualitas SDM di perguruan tinggi banyak faktor yang memengaruhi keberhasilannya, salah satunya dengan menyesuaikan metode pengajaran dan pembelajaran yang tepat bagi mahasiswa generasi $Z$ khususnya mahasiswa Departemen Manajemen, sehingga diharapkan kualitas SDM semakin meningkat. Peningkatan kualitas sumberdaya manusia khususnya di perguruan tinggi salah satunya dipengaruhi oleh gaya belajar diantaranya adalah gaya belajar auditori, visual, dan kinestetik. Untuk meningkatkan prestasi mahasiswa generasi $\mathrm{Z}$ perlu dilakukan penelitian mengenai gaya belajar apa saja yang dimiliki mahasiswa agar dapat mengevaluasi metode pembelajaran di Departemen Manajemen. Oleh karena itu, penelitian mengenai pengaruh gaya belajar terhadap prestasi mahasiswa generasi $\mathrm{Z}$ penting, maka dalam penelitian ini dilakukan analisis pengaruh gaya belajar terhadap prestasi mahasiswa generasi Z Departemen Manajemen Institut Pertanian Bogor.

\section{METODE PENELITIAN}

Penelitian dilaksanakan di lingkungan Institut Pertanian Bogor yang berada di Bogor, Jawa Barat dengan mengambil objek penelitian adalah mahasiswa aktif S1 Departemen Manajemen FEM IPB angkatan 2015-2018. Waktu pelaksanaan penelitian ini pada bulan April 2019-Mei 2019.

Jenis dan sumber data yang digunakan dalam penelitian ini adalah data primer dan data sekunder yang bersifat kualitatif dan kuantitatif. Data primer diperoleh langsung dari kegiatan pengisian kuesioner yang diberikan kepada mahasiswa generasi $\mathrm{Z}$ Departemen Manajemen FEM IPB angkatan 2015-2018 Sedangkan data sekunder penelitian ini diperoleh dari data akademik Departemen Manajemen FEM IPB, buku-buku, jurnal, internet, skripsi dan literatur baik online maupun offline. Teknik pengumpulan data menggunakan kuesioner dengan membagikan daftar pernyataan yang telah disediakan kepada responden. Kuesioner dalam penelitian ini berisikan daftar pernyataan yang tersusun berdasarkan teoriteori dan literatur yang berkaitan dengan gaya belajar dan prestasi. Populasi dalam penelitian ini adalah mahasiswa S1 Departemen Manajemen angkatan 5255. Cara menentukan jumlah sampel dalam penelitian ini menggunakan metode nonprobability sampling dengan teknik purposive sampling. Jumlah sampel yang diambil dalam penelitian ini sebanyak 58 orang. Dalam penelitian ini ada kriteria yang disyaratkan kepada 
reponden yakni memiliki IPK kurang dari 3.00.

Metode analisis data yang digunakan dalam penelitian ini adalah analisis deskriptif, SEM-PLS. Analisis deskriptif berfungsi untuk mendiskripsikan atau memberi gambaran terhadap obyek yang diteliti melalui data sampel atau populasi sebagaimana adanya, tanpa melakukan analisis dan membuat kesimpulan yang berlaku untuk umum (Sugiyono 2011). Penelitian ini akan menggunakan penilaian persepsi melalui 4 skala likert dengan rentang nilai sebagai berikut.

Tabel 2.

Rentang Skala

\begin{tabular}{cc}
\hline Rentang Skala & Jawaban Pertanyaan \\
\hline $1.00<x \leq 1.75$ & Sangat Tidak Setuju \\
$1.75<x \leq 2.50$ & Tidak Setuju \\
$2.50<x \leq 3.25$ & Setuju \\
$3.25<x \leq 4.00$ & Sangat Setuju \\
\hline
\end{tabular}

Analisis SEM-PLS menggunakan dua evaluasi yakni evaluasi outer model dan inner model. Evaluasi outer model reflektif dilakukan pada first order. Evaluasi berdasarkan tiga criteria yaitu convergent validity, discriminant validity, dan composite reliability, sedangkan pengujian inner model ada dua kriteria yaitu R-square pada konstruk first order untuk mengidentifikasi kategori model dan path coefficient untuk pengujian hipotesis (Ghozaly, 2014). Metode SEM-PLS terdiri dari dua jenis variabel yakni variabel laten dan variabel manifes. Variabel laten biasa disebut inner model dan variabel manifes biasa disebut outer model.

\section{HASIL DAN PEMBAHASAN}

\section{Karakteristik responden}

Responden dalam penelitian ini sebanyak 58 orang yang berasal dari mahasiswa aktif Departemen Manajemen angkatan 52-55. Berdasarkan responden yang mengisi kuesioner maka diketahui bahwa mahasiswa yang memiliki IPK kurang dari 3.00 angkatan 52-55 didominasi oleh laki-laki sebanyak 40 orang dengan persentase $69 \%$, sedangkan perempuan sebanyak 18 orang dengan persentase $31 \%$. Berdasarkan usia mahasiswa Departemen Manajemen angkatan 52-55 berusia 19 tahun dengan persentase $39.7 \%$. Hal ini menunjukkan bahwa mahasiswa Departemen Manajemen tergolong dalam generasi $\mathrm{Z}$ atau net generation. Jalur penerimaan mahasiswa IPB didominasi melalui jalur undangan tanpa tes (SNMPTN) dikarenakan IPB memberikan prioritas pada jalur tersebut. Sebanyak 10 mahasiswa Departemen Manajemen menerima beasiswa dengan persentase $17.2 \%$ sedangkan yang tidak menerima beasiswa sebanyak 48 mahasiswa dengan persentase $82.8 \%$. sebanyak 42 orang dengan persentase $72.4 \%$ mahasiswa aktif dalam berorganisasi sedangkan sebanyak 16 orang dengan persentase $27.6 \%$ mahasiswa tidak aktif berorganisasi. Selanjutnya dilakukan tabulasi silang pada beberapa karakteristik. Berikut tabulasi silang antara karakteristik IPK dan keaktifan organisasi.

Tabel 3.

Tabulasi Silang IPK dan Organisasi

\begin{tabular}{cccc}
\hline IPK & $\begin{array}{c}\text { Aktif } \\
\text { Organisasi }\end{array}$ & $\begin{array}{c}\text { Tidak Aktif } \\
\text { Organisasi }\end{array}$ & Total \\
\hline$<2.00$ & 2 & 2 & 4 \\
$>2.00-2.50$ & 7 & 7 & 11 \\
$>2.50-3.00$ & 33 & 7 & 40 \\
\hline Total & 42 & 16 & 58 \\
\hline
\end{tabular}

Berdasarkan Tabel 3 dapat dilihat bahwa mayoritas mahasiswa berperan aktif mengikuti organisasi sebanyak 42 orang sedangkan yang tidak aktif mengikuti organisasi sebanyak 16 . Mayoritas mahasiwa yang aktif dalam organisasi yaitu dengan IPK $>2.50-3.00$ berjumlah 40 orang. Data tersebut menunjukkan bahwa mayoritas mahasiswa aktif dalam berorganisasi, dengan aktif berorganisasi diharapkan mampu meningkatkan kemampuan komunikasi dan kerjasama dengan baik. Selanjutnya dilakukan tabulasi silang antara IPK dan jalur masuk. Tabulasi IPK dan jalur masuk dapat dilihat pada Tabel 4.

Tabel 4.

\begin{tabular}{lcccccc}
\multicolumn{1}{c}{ Tabulasi Silang IPK dan Jalur Masuk } \\
\hline IPK & $\begin{array}{c}\text { Peasiswa } \\
\text { Utusan } \\
\text { Daerah }\end{array}$ & $\begin{array}{c}\text { Internasional/ } \\
\text { Hafidz/ } \\
\text { Ketua Osis/ } \\
\text { Lainnya }\end{array}$ & SNMPTN & SBMPTN & UTMI & Total \\
\hline$<2.00$ & 1 & 0 & 2 & 0 & 1 & 4 \\
$>2.00-2.50$ & 2 & 0 & 4 & 6 & 2 & 14 \\
$>2.50-3.00$ & 4 & 3 & 26 & 14 & 3 & 40 \\
\hline Total & 7 & 3 & 22 & 20 & 6 & 58 \\
\hline
\end{tabular}

Berdasarkan Tabel 4 dapat dilihat bahwa mahasiswa dengan IPK kurang dari 3.00 didominasi oleh mahasiswa dengan jalur masuk SNMPTN sebanyak 22 orang dan SBMPTN sebanyak 20 orang. Selanjutnya jalur masuk beasiswa utusan daerah sebanyak 7 orang, UTMI sebanyak 6 orang dan jalur masuk Prestasi Internasional/ Hafidz/ Ketua Osis sebanyak 3 orang. 


\section{Persepsi Mahasiswa Generasi Z terhadap Gaya Belajar}

Mahasiswa Departemen Manajemen FEM IPB memiliki persepsi mengenai variabel gaya belajar. Gaya belajar pada penelitian terbagi menjadi tiga indikator yaitu gaya belajar visual, gaya belajar auditori, dan gaya belajar kinestetik. Masing-masing indikator memiliki pernyataan dengan nilai yang berbeda-beda. Berikut hasil analisis deskriptif persepsi mahasiswa generasi $\mathrm{Z}$ terhadap gaya belajar visual, auditori, dan kinestetik.

\section{Persepsi Mahasiswa terhadap Gaya Belajar Visual}

Gaya belajar visual adalah suatu bentuk gaya belajar dengan cara melihat, memandang suatu obyek yang dipelajari. Orang yang memiliki gaya belajar visual senang dengan melihat ilustrasi, gambar, bentuk dan sangat mudah menyerap informasi dengan melihat. Hasil analisis deskriptif, persepsi mahasiswa generasi $\mathrm{Z}$ terhadap gaya belajar dapat dilihat pada Tabel 5.

Tabel 5.

Persepsi Mahasiswa Terhadap Gaya Belajar Visual

\begin{tabular}{|c|c|c|c|}
\hline No & Pernyataan & Rataan & Keterangan \\
\hline 1 & $\begin{array}{l}\text { Selalu ingin tampak rapi dan teratur dalam hal } \\
\text { berpakaian maupun presentasi }\end{array}$ & 3.37 & Sangat Setuju \\
\hline 2 & $\begin{array}{l}\text { Ketika berbicara, cenderung berbicara dengan } \\
\text { nada yang cepat }\end{array}$ & 2.68 & Setuju \\
\hline 3 & $\begin{array}{l}\text { Perencana dan pengatur jangka panjang yang } \\
\text { baik dalam segala hal }\end{array}$ & 2.84 & Setuju \\
\hline 4 & $\begin{array}{l}\text { Saat belajar, cenderung mengingat dengan cara } \\
\text { melihat daripada mendengar }\end{array}$ & 2.79 & Setuju \\
\hline 5 & $\begin{array}{l}\text { Suka mengingat materi kuliah dengan cara } \\
\text { menghubungkan segala sesuatu di lapangan }\end{array}$ & 3.01 & Setuju \\
\hline 6 & $\begin{array}{l}\text { Ketika suasana kelas/sekitar sedang gaduh, } \\
\text { masih dapat berkonsentrasi dengan apa yang } \\
\text { sedang dipelajari }\end{array}$ & 1.87 & Tidak Setuju \\
\hline 7 & $\begin{array}{l}\text { Ketika dosen menjelaskan penugasan secara } \\
\text { lisan, sering tidak paham dan meminta bantuan } \\
\text { teman untuk mengulanginya }\end{array}$ & 2.82 & Setuju \\
\hline 8 & $\begin{array}{l}\text { Terbiasa membaca referensi (buku, artikel, jurnal, } \\
\text { materi perkuliahan) dengan cepat dan tekun }\end{array}$ & 2.00 & Tidak Setuju \\
\hline 9 & $\begin{array}{l}\text { Sering mencoret-coret tanpa arti di buku catatan } \\
\text { saat dosen menjelaskan }\end{array}$ & 2.63 & Setuju \\
\hline 10 & $\begin{array}{l}\text { Sering mencatat di buku catatan/kertas saat } \\
\text { dosen menjelaskan }\end{array}$ & 2.65 & Setuju \\
\hline \multirow[t]{2}{*}{11} & $\begin{array}{l}\text { Mudah memahami slide powerpoint (tabel/ } \\
\text { diagram) dari pada mendengarkan penjelasan } \\
\text { dosen }\end{array}$ & 2.51 & Setuju \\
\hline & Total & 2.65 & Setuju \\
\hline
\end{tabular}

Berdasarkan Tabel 5 mahasiswa telah mempersepsikan bagaimana gaya belajar visual. Mahasiswa generasi $\mathrm{Z}$ sangat memperhatikan penampilan dan performance saat berada di publik. Mahasiswa sangat setuju dengan rataan 3.37 dalam hal berpakaian dan presentasi selalu ingin tampak

rapi dan teratur. Individu yang memiliki gaya belajar visual cenderung memperhatikan hal-hal secara detail dan mengandalkan penglihatan. Mahasiswa setuju bahwa mengingat pelajaran cenderung lebih mudah dengan cara melihat dan mudah mengingat materi kuliah dengan cara menghubungkan segala sesuatu yang dilihat di lapangan. Hal ini menunjukkan bahwa mahasiswa generasi $\mathrm{Z}$ saat ini mudah menerima pelajaran dengan cara melihat gambar, bentuk, pola, huruf, dan angka. Mata kuliah yang diselingi dengan video, slide powerpoint, dan grafik merupakan salah satu solusi untuk mahasiswa yang memiliki gaya belajar visual untuk lebih mudah menyerap materi selama perkuliahan berlangsung. Mahasiswa setuju bahwa dalam segala hal adalah pengatur dan perencana jangka panjang yang baik, sehingga dalam melakukan segala hal sesuai dengan yang telah direncanakan. Mahasiswa yang memiliki gaya belajar visual ketika diberikan penugasan oleh dosen secara lisan sering tidak paham, sehingga meminta bantuan kepada teman untuk mengulangi penjelasan dari dosen. Mahasiswa tidak setuju bahwa saat membaca referensi (buku, artikel, jurnal, materi perkuliahan) dengan cepat dan tekun, Selain itu mahasiswa sering menulis dibuku catatan ketika dosen menjelaskan materi sehingga memudahkan untuk mengingat kembali materi perkuliahan, namun tidak setuju dengan rataan 1.87 ketika kelas sedang gaduh mahasiswa dapat berkonsentrasi dengan apa yang dipelajari. Mahasiswa lebih menyukai suasana yang tenang sehingga dapat berkonsentrasi dan menerima materi perkuliahan dengan baik.

\section{Persepsi Mahasiswa terhadap Gaya Belajar Auditori} Gaya belajar auditori adalah gaya belajar dengan cara mengandalkan pendengaran untuk menerima informasi dan mengingat materi kuliah. Berikut persepsi mahasiswa generasi $Z$ terhadap gaya belajar pada Tabel 6 .

Tabel 6.

\begin{tabular}{|c|c|c|c|}
\hline No & Pernyataan & Rataan Skor & Keterangan \\
\hline 1 & $\begin{array}{l}\text { Saat kelas sedang gaduh, tidak bisa } \\
\text { berkonsentrasi }\end{array}$ & 2.96 & Setuju \\
\hline 2 & $\begin{array}{l}\text { Ketika sedang membaca referensi (buku, } \\
\text { artikel, jurnal, materi perkuliahan) sering } \\
\text { menggerakkan bibir mengikuti kalimat } \\
\text { daripada membaca dalam hati. }\end{array}$ & 2.74 & Setuju \\
\hline 3 & $\begin{array}{l}\text { Lebih mudah memahami bacaan dengan } \\
\text { bersuara keras }\end{array}$ & 2.67 & Setuju \\
\hline 4 & $\begin{array}{l}\text { Lebih mudah memahami materi kuliah saat } \\
\text { dosen menjelaskan dengan intonasi yang keras }\end{array}$ & 2.87 & Setuju \\
\hline
\end{tabular}




\begin{tabular}{clcc}
5 & $\begin{array}{l}\text { Lebih suka presentasi daripada menulis tugas } \\
\text { makalah }\end{array}$ & 2.84 & Setuju \\
$6 \quad \begin{array}{l}\text { Selalu berbicara dengan lancar dan tidak } \\
\text { gugup saat berdiskusi di dalam kelas }\end{array}$ & 2.63 & Setuju \\
$7 \quad \begin{array}{l}\text { Suka berbicara, berdiskusi, dan menjelaskan } \\
\text { sesuatu panjang lebar }\end{array}$ & 2.51 & Setuju \\
$8 \quad \begin{array}{l}\text { Lebih mudah mengingat yang disampaikan } \\
\text { oleh dosen dengan cara mendengar daripada } \\
\text { melihat di papan tulis atau slide powerpoint }\end{array}$ & 2.46 & $\begin{array}{l}\text { Tidak } \\
\text { Totuju }\end{array}$ \\
\hline & \multicolumn{2}{c}{2.71} & Setuju \\
\hline
\end{tabular}

Berdasarkan Tabel 6 diketahui mahasiswa setuju dengan rataan 2.96 saat kelas sedang gaduh, mahasiswa tidak dapat berkonsentrasi saat belajar di kelas. Ketika kelas sedang gaduh mahasiswa yang memiliki gaya belajar auditori akan terganggu karena dalam mengingat materi kuliah mereka mengandalkan pendengaran untuk memahami dan mengingat materi pelajaran. Mahasiswa yang memiliki gaya belajar auditori setuju ketika membaca referensi (buku, artikel, jurnal, materi perkuliahan) mengikuti kalimat dengan menggerakkan bibir dan membacanya dengan suara keras untuk mempermudah memahami materi perkuliahan. Mahasiswa yang memiliki gaya belajar auditori setuju lebih suka presentasi, berdiskusi, berbicara, dan menjelaskan sesuatu dengan panjang lebar, lancar dan tidak gugup saat sesi diskusi dan presentasi berlangsung. Saat kegiatan pembelajaran berlangsung, mahasiswa juga lebih mudah memahami mata kuliah ketika dosen menjelaskan dengan intonasi yang jelas, namun mahasiswa tidak setuju dengan rataan 2.46 bahwa lebih mudah mengingat materi yang disampaikan oleh dosen dengan cara mendengar daripada melihat di papan tulis atau slide powerpoint. Sehingga penjelasan dosen lebih mudah diingat apabila dijelaskan dengan intonasi yang jelas disertai materi ajar yang tersedia di slide powerpoint atau di papan tulis.

\section{Persepsi Mahasiswa terhadap Gaya Belajar Kinestetik}

Gaya belajar kinestetik adalah gaya belajar yang mengharuskan individu bersangkutan menyentuh sesuatu yang memberikan informasi agar bisa mengingatnya. Mahasiswa yang memiliki gaya belajar kinestetik cenderung menyukai sistem pembelajaran yang berorientasi pada fisik dan banyak pergerakan tubuh, tidak dapat diam dalam waktu lama dan banyak menggunakan isyarat tubuh sehingga dapat menerima informasi yang disampaikan oleh lawan bicaranya. Berikut persepsi mahasiswa terhadap gaya belajar kinestetik pada Tabel 7.
Tabel 7.

Persepsi Mahasiswa Terhadap Gaya Belajar Kinestetik

\begin{tabular}{clcc}
\hline No & \multicolumn{1}{c}{ Pernyataan } & Rataan Skor & Keterangan \\
\hline 1 & $\begin{array}{l}\text { Lebih mudah memahami penjelasan dari dosen } \\
\text { saat duduk di barisan depan }\end{array}$ & 2.87 & Setuju \\
2 & $\begin{array}{l}\text { Lebih suka memahami mata kuliah saat } \\
\text { responsi (Turun lapang/mengerjakan soal) }\end{array}$ & 3.24 & Setuju \\
3 & $\begin{array}{l}\text { Lebih mudah memahami materi yang } \\
\text { dipelajari ketika menggerakkan anggota badan }\end{array}$ & 2.93 & Setuju \\
4 & $\begin{array}{l}\text { Ketika membaca, menggunakan jari untuk } \\
\text { menunjuk kata-kata }\end{array}$ & 2.27 & $\begin{array}{l}\text { Tidak } \\
\text { Setuju }\end{array}$ \\
5 & $\begin{array}{l}\text { Bosan ketika berdiam diri saat di kelas dalam } \\
\text { waktu lama }\end{array}$ & 3.53 & Sangat \\
6 & $\begin{array}{l}\text { Saat presentasi, melakukan dengan gerakan } \\
\text { (gerakan tangan/berjalan/serong kiri atau } \\
\text { kanan) }\end{array}$ & 3.08 & Setuju \\
7 & $\begin{array}{l}\text { Menyukai aktivitas di kelas yang } \\
\text { membutuhkan pergerakan anggota tubuh }\end{array}$ & 3.03 & Setuju \\
8 & $\begin{array}{l}\text { Ketika jam perkuliahan, menyukai sesi } \\
\text { permainan/ice breaking yang dilakukan oleh } \\
\text { dosen }\end{array}$ & 3.15 & Setuju \\
\hline & Total & 3.01 & Setuju \\
\hline
\end{tabular}

Berdasarkan Tabel 7 diketahui mahasiswa yang memiliki gaya belajar kinestetik sangat setuju dengan rataan 3.53 merasa bosan ketika berdiam diri di dalam kelas dalam waktu lama. Individu yang memiliki gaya belajar kinestetik mengharuskan dirinya untuk melakukan banyak pergerakan tubuh dan lebih mudah memahami apa yang dipelajari ketika menggerakkan anggota badan. Saat presentasi, mahasiswa yang memiliki gaya belajar kinestetik lebih banyak melakukan pergerakan tubuh seperti serong kanan, serong kiri, berjalan, atau menggerakkan tangan. Hal ini menunjukkan bahwa dengan bergerak, mahasiswa mampu membawa diri menjadi lebih nyaman dalam proses pembelajaran. Saat di dalam kelas mahasiswa lebih mudah memahami penjelasan dari dosen saat duduk di barisan paling depan dan menyukai sesi permainan/ice breaking yang dilakukan oleh dosen. Mayoritas mahasiswa setuju lebih suka memahami mata kuliah saat responsi dengan turun lapang atau mengerjakan soal-soal yang diberikan oleh dosen. Turun lapang menjadi salah satu solusi yang dapat diterapkan untuk mahasiswa yang memiliki gaya belajar kinestetik. Selain itu tim pengajar dapat menerapkan sistem belajar di luar ruangan dan tidak terpaku dengan suasana yang tegang di dalam kelas. Departemen Manajemen perlu adanya evaluasi sistem pembelajaran yang cocok untuk mahasiswa generasi $\mathrm{Z}$ terutama pada mahasiswa yang memiliki gaya belajar kinestetik. Sebaiknya perlu adanya materi perkuliahan yang dapat diterapkan langsung dikehidupan seharihari agar dapat diterima oleh mahasiswa selama proses pembelajaran. Hal ini ditunjukkan bahwa mahasiswa generasi $\mathrm{Z}$ setuju terhadap gaya belajar kinestetik. 


\section{Persepsi Mahasiswa Generasi Z Departemen Mana- jemen FEM IPB terhadap Prestasi}

Mahasiswa Departemen Manajemen FEM IPB memiliki persepsi mengenai variabel prestasi. Prestasi pada penelitian ini terbagi menjadi dua yaitu penilaian acuan norma berdasarkan indeks prestasi kumulatif (IPK) dan penilaian acuan kriteria (ranah kognitif, ranah afektif, dan ranah psikomotorik). Masingmasing indikator memiliki pernyataan dengan nilai yang berbeda-beda. Berikut tabel analisis deskriptif prestasi pada Tabel 12.

\section{Penilaian Acuan Norma (Norm-Refrenced Assessment)}

Penelitian ini menggunakan pendekatan PAN (Penilaian Acuan Norma), prestasi belajar seseorang peserta didik diukur dengan cara membandingkannya dengan prestasi yang dicapai teman-teman sekelas atau sekelompoknya (Syah 2014). Penilaian Acuan Norma (PAN) pada mahasiswa dapat dilihat dari Indeks Prestasi Kumulatif (IPK).

Tabel 8.

Indeks Prestasi Kumulatif Mahasiswa Manajemen

\begin{tabular}{cc}
\hline IPK & Jumlah \\
\hline$<2.00$ & $\mathbf{4}$ \\
$>2.00-2.50$ & 14 \\
$>2.50-3.00$ & 40 \\
\hline Total & $\mathbf{5 8}$ \\
\hline
\end{tabular}

Berdasarkan Tabel 8 diatas diketahui bahwa sebanyak 40 mahasiswa Departemen Manajemen memiliki IPK > 2.50-3.00, sebanyak 14 mahasiswa memiliki IPK $>2.00-2.50$, dan mahasiswa yang memiliki IPK $<2.00$ sebanyak 4 mahasiswa.

\section{Penilaian Acuan Kriteria (Criterion-Refrenced Assessment)}

Dalam penilaian menggunakan pendekatan PAK (Penilaian Acuan Kriteria) merupakan proses pengukuran prestasi belajar dengan cara membandingkan pencapaian seorang siswa dengan berbagai perilaku ranah yang telah ditetapkan secara baik (well-defined domain behaviors) sebagai patokan absolut. Perilaku ranah tesebut terdiri dari ranah cipta (kognitif), ranah rasa (afektif), dan ranah karsa (psikomotorik).

\section{Kognitif}

Kognitif berorientasi yaitu kemampuan berpikir yang mencakup kemampuan intelektual sederhana seperti pengamatan, ingatan, pemahaman, aplikasi/ penerapan, analisis, dan sintesis. Berikut persepsi mahasiswa terhadap ranah kognitif pada Tabel 9.
Tabel 9.

\begin{tabular}{|c|c|c|c|}
\hline No & Pernyataan & Rataan Skor & Keterangan \\
\hline 1 & $\begin{array}{l}\text { Selama kuliah, pengetahuan yang dimiliki } \\
\text { menjadi lebih baik dan bermanfaat bagi } \\
\text { pencapaian prestasi }\end{array}$ & 3.05 & Setuju \\
\hline 2 & $\begin{array}{l}\text { Selama kuliah, Mampu mengaplikasikan } \\
\text { konsep manajerial dengan baik yang } \\
\text { bermanfaat bagi pencapaian prestasi }\end{array}$ & 2.81 & Setuju \\
\hline 3 & $\begin{array}{l}\text { Selama kuliah mampu menganalisis suatu } \\
\text { permasalahan baik akademik maupun non } \\
\text { akademik dengan baik yang bermanfaat bagi } \\
\text { pencapaian prestasi }\end{array}$ & 2.84 & Setuju \\
\hline 4 & $\begin{array}{l}\text { Selama kuliah, mudah memahami materi yang } \\
\text { disampaikan oleh Dosen sehingga menunjang } \\
\text { proses belajar }\end{array}$ & 2.48 & $\begin{array}{l}\text { Tidak } \\
\text { Setuju }\end{array}$ \\
\hline 5 & $\begin{array}{l}\text { Selama kuliah mampu mengingat materi } \\
\text { kuliah dengan baik sehingga menunjang } \\
\text { proses belajar }\end{array}$ & 2.27 & $\begin{array}{l}\text { Tidak } \\
\text { Setuju }\end{array}$ \\
\hline 6 & $\begin{array}{l}\text { Memiliki kemampuan berbahasa Indonesia } \\
\text { yang baik }\end{array}$ & 3.12 & Setuju \\
\hline 7 & $\begin{array}{l}\text { Memiliki kemampuan berbahasa Inggris yang } \\
\text { baik }\end{array}$ & 2.62 & Setuju \\
\hline 8 & $\begin{array}{l}\text { Memiliki kemampuan berbahasa Asing yang } \\
\text { baik }\end{array}$ & 1.89 & $\begin{array}{l}\text { Tidak } \\
\text { Setuju }\end{array}$ \\
\hline 9 & $\begin{array}{l}\text { Memiliki pemahaman dalam pengajaran } \\
\text { secara online melalui video youtube atau situs } \\
\text { pendidikan di internet }\end{array}$ & 2.94 & Setuju \\
\hline 10 & $\begin{array}{l}\text { Memiliki kemampuan mengerjakan lebih dari } \\
\text { dua pekerjaan secara bersamaan (multitasking) }\end{array}$ & 2.62 & Setuju \\
\hline & Total & 2.66 & Setuju \\
\hline
\end{tabular}

Berdasarkan Tabel 9 menunjukkan bahwa mahasiswa setuju terhadap kognitif selama mengikuti perkuliahan di Departemen Manajemen. Selama kuliah, mahasiswa mampu mengaplikasikan konsep manajerial dan pengetahuan yang dimiliki menjadi lebih baik dan bermanfaat bagi pencapaian prestasi. Mahasiswa mampu menganalisis suatu permasalahan baik akademik mauapun non akademik sehingga mampu menyesuaikan dengan kondisi apapun yang ada di Departemen Manajemen.

Era digital native mahasiswa memiliki kemampuan berbahasa Indonesia dengan baik dalam berkomunikasi dengan rataan 3.12, namun mahasiswa tidak setuju memiliki kemampuan berbahasa asing dengan rataan 1.89. Memiliki kemampuan Bahasa Inggris maupun bahasa asing dirasa penting agar dapat beradaptasi di era revolusi industri 4.0 khususnya nasional maupun internasional. Sebaiknya ada pembelajaran yang menggunakan bahasa asing agar kemampuan berbahasa mahasiswa terasah dan semakin baik. Mahasiswa generasi Z juga memiliki kemampuan mengerjakan lebih dari satu pekerjaan secara bersamaan (multitasking) seperti belajar dengan mendengarkan musik.

Selama kuliah mahasiswa tidak setuju mampu mengingat materi kuliah dengan baik dan 
sulit memahami materi yang disampaikan oleh dosen. Namun mahasiswa saat ini lebih mudah dalam mengakses materi perkuliahan dan memiliki pemahaman dalam pengajaran secara online melalui video youtube atau situs pendidikan di internet sehingga dapat menunjang pemahaman materi perkuliahan, adanya inovasi yang dilakukan oleh tim pengajar dalam pemanfaatan internet untuk menunjang pemahaman mahasiswa terkait materi perkuliahan.

\section{Afektif}

Afektif adalah berkaitan dengan penerimaan, sambutan, apresiasi (sikap menghargai), internalisasi (pendalaman) dan karakterisasi (penghayatan). Berikut persepsi mahasiswa terhadap afektif pada Tabel 10.

Tabel 10.

\begin{tabular}{|c|c|c|c|}
\hline No & Pernyataan & Rataan Skor & Keterangan \\
\hline 1 & $\begin{array}{l}\text { Ketika presentasi berakhir, bersedia menerima } \\
\text { kritik dan saran dari orang lain }\end{array}$ & 3.36 & $\begin{array}{l}\text { Sangat } \\
\text { Setuju }\end{array}$ \\
\hline 2 & $\begin{array}{l}\text { Mengikuti kegiatan di luar perkuliahan (seperti } \\
\text { seminar) yang dapat menambah pemahaman } \\
\text { mata kuliah }\end{array}$ & 2.82 & Setuju \\
\hline 3 & $\begin{array}{l}\text { Sering bertanya kepada dosen saat } \\
\text { berlangsungnya diskusi }\end{array}$ & 2.18 & $\begin{array}{l}\text { Tidak } \\
\text { Setuju }\end{array}$ \\
\hline 4 & $\begin{array}{l}\text { Selalu hadir dalam perkuliahan maupun } \\
\text { responsi }\end{array}$ & 2.77 & Setuju \\
\hline 5 & $\begin{array}{l}\text { Saat perkuliahan/responsi berlangsung, } \\
\text { menyimak penjelasan dosen/asisten dosen } \\
\text { dengan baik }\end{array}$ & 2.70 & Setuju \\
\hline 6 & $\begin{array}{l}\text { Ketika menyelesaikan suatu masalah, } \\
\text { menerapkan teori yang sudah didapatkan di } \\
\text { kelas }\end{array}$ & 2.77 & Setuju \\
\hline 7 & $\begin{array}{l}\text { Memiliki kemampuan memimpin kelompok/ } \\
\text { organisasi dengan baik }\end{array}$ & 2.82 & Setuju \\
\hline & Total & 2.77 & Setuju \\
\hline
\end{tabular}

Berdasarkan Tabel 10 menunjukkan bahwa mahasiswa setuju terhadap afektif. Mahasiswa sangat setuju dengan rataan 3.36 bahwa ketika presentasi berakhir, bersedia menerima kritik dan saran dari orang lain. Hal ini menunjukkan bahwa mahasiswa mampu menerima saran baik positif dan negatif dari orang lain. Selain itu mahasiswa juga aktif dalam kegiatan di luar perkuliahan (seminar) yang dapat menambah pemahaman dan wawasan baru terkait mata kuliah yang telah diajarkan. Selama perkuliahan maupun responsi berlangsung mahasiswa hadir dalam perkuliahan dan menyimak penjelasan dosen atau asisten dosen dengan baik. Dalam menyelesaiakan suatu permasalahan baik dikelas, organisasi, lingkungan sekitar mahasiswa mampu menerapkan teori yang sudah didapatkan dikelas seperti teori manajerial dan memiliki kemampuan memimpin kelompok atau organisasi yang diikuti selama kuliah di IPB. Namun mahasiswa tidak setuju dengan rataan 2.18 sering bertanya kepada dosen saat berlangsungnya diskusi.

\section{Psikomotorik}

Psikomotorik yaitu berkaitan dengan kemampuan bergerak dan bertindak, kecakapan ekspresi verbal dan non verbal. Berikut persepsi mahasiswa terhadap psikomotorik pada Tabel 11.

Tabel 11.

Persepsi Mahasiswa Terhadap Psikomotorik

\begin{tabular}{clcc}
\hline No & \multicolumn{1}{c}{ Pernyataan } & Rataan Skor & Keterangan \\
\hline 1 & $\begin{array}{l}\text { Selama kuliah memiliki keterampilan yang } \\
\text { baik dalam mengaplikasikan komputer }\end{array}$ & 2.98 & Setuju \\
2 & $\begin{array}{l}\text { Selama kuliah memiliki kemampuan mengolah } \\
\text { data dengan baik menggunakan Microsoft } \\
\text { Office/SPSS/SEM/ Mini Tab }\end{array}$ & 2.81 & Setuju \\
3 & $\begin{array}{l}\text { Selama kuliah mampu menyajikan bahan } \\
\text { presentasi (Power Point) dengan baik }\end{array}$ & 3.13 & Setuju \\
4 & $\begin{array}{l}\text { Selama kuliah mampu menyelesaikan tugas } \\
\text { membuat video/poster/makalah dengan baik }\end{array}$ & 2.94 & Setuju \\
5 & $\begin{array}{l}\text { Selama kuliah mahir dalam mengakses } \\
\text { informasi di internet }\end{array}$ & 3.24 & Setuju \\
6 & $\begin{array}{l}\text { Memiliki kemampuan menyampaikan sesuatu } \\
\text { secara lisan kepada orang lain dengan baik }\end{array}$ & 2.86 & Setuju \\
7 & $\begin{array}{l}\text { Memiliki kemampuan menyampaikan sesuatu } \\
\text { secara tulisan kepada orang lain dengan baik }\end{array}$ & 2.84 & Setuju \\
\hline & $\quad$ Total & 2.97 & Setuju \\
\hline
\end{tabular}

Berdasarkan Tabel 11 menunjukkan bahwa mahasiswa setuju terhadap psikomotorik yang menekankan pada aspek keterampilan motorik. Selama perkuliahan mahasiswa mahir dalam mengakses informasi di internet dengan rataan 3.24. Mahasiswa memiliki keterampilan dalam mengaplikasikan komputer maupun mengolah data dengan menggunakan Microsoft Office/SPSS/SEM/ Mini Tab dengan rataan 2.81. selain itu mahasiswa mampu meyajikan bahan presentasi berupa powerpoint dan memiliki kemampuan menyampaikan sesuatu secara tertulis maupun lisan. Hal ini menunjukkan bahwa mahasiswa generasi Z Departemen Manajemen mampu menyelesaikan tugas-tugas yang diberikan oleh dosen yang menggunakan komputer, internet, dan aplikasi sejenis. Dalam era revolusi industri 4.0 perlu adanya keahlian dan keterampilan dalam menggunakan teknologi digital agar meningkatkan kualitas sumberdaya manusia di Indonesia.

\section{Pengaruh Gaya Belajar terhadap Prestasi MahasiswaGenerasi Z Departemen Manajemen FEM IPB}

Penelitian ini untuk melihat pengaruh gaya 
belajar terhadap prestasi mahasiswa generasi $\mathrm{Z}$ Departemen Manajemen FEM IPB. Alat analisis yang digunakan adalah SEM dengan pendekatan Patrial Least Square (PLS). Variabel-variabel pada penelitian ini adalah gaya belajar dan prestasi. Indikator pengukuran gaya belajar yaitu visual, auditori, dan kinestetik. Indikator penilaian prestasi yaitu IPK, kognitif, afektif, dan psikomotorik.

\section{Evaluasi Outer Model}

\section{Convergent Validity}

Convergent Validity dinilai berdasarkan korelasi antar item skor dengan construct skor yang dihitung dengan PLS (Ghozali 2014). Indikator dikatakan valid apabila loading factornya bernilai diatas 0.50 . Apabila terdapat indikator yang kurang dari 0.50 maka indikator tersebut harus dihapus dan dilakukan perhitungan ulang. Model dan perhitungan awal dapat dilihat pada Gambar 3.

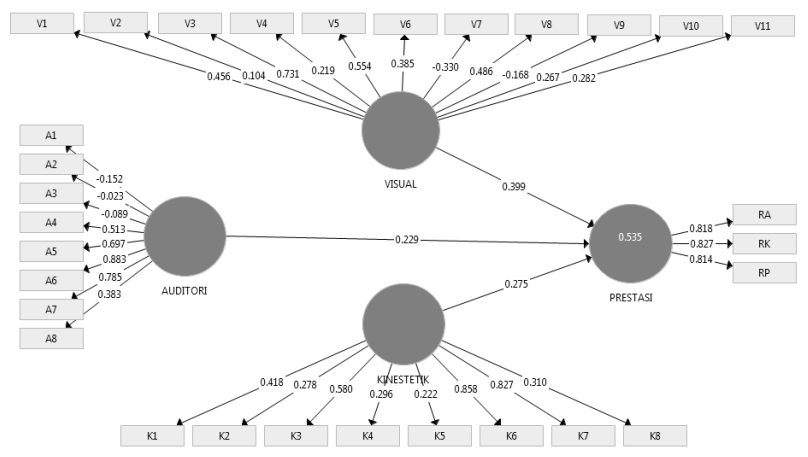

Gambar 3. Model dan perhitungan awal loading factor

Berdasarkan Gambar 3 terdapat 17 indikator yang tidak memenuhi kriteria dengan loading factor dibawah 0.50 . Indikator yang tidak memenuhi kriteria tersebut dihilangkan dan dilakukan perhitungan ulang. Setelah melakukan langkah tersebut didapatkan model dan perhitungan akhir. Berikut merupakan model dan perhitungan akhir pada Gambar 4 .

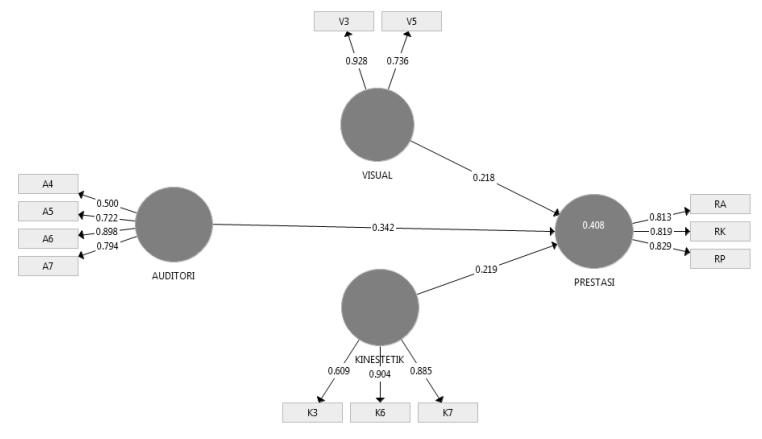

Gambar 4. Model dan perhitungan akhir loading factor

Berdasarkan Gambar 4 dapat dinyatakan bahwa indikator kemampuan akademik berupa pencapaian IPK tidak dapat merefleksikan variabel prestasi dalam hal ini mahasiswa aktif Departemen Manajemen angkatan 2015-2019, melainkan prestasi sesungguhnya dapat ditunjukkan oleh kognitif yang dicerminkan (RK), selain itu juga dicerminkan dari afektif (RA), dan psikomotorik (RP). Semua indikator tersebut mencerminkan prestasi mahasiswa yang merupakan hasil selama proses perkuliahan di Departemen Manajemen dan diaplikasikan dalam kehidupan pasca kampus.

Indikator yang merefleksikan variabel visual adalah perencana dan pengatur jangka panjang yang baik (V3) suka mengingat materi kuliah dengan cara menghubungkan segala sesuatu di lapang (V5). Indikator yang merefleksikan variabel auditori adalah lebih mudah memahami materi kuliah saat dosen menjelaskan dengan intonasi yang keras (A4) lebih suka presentasi daripada menulis tugas makalah (A5) berbicara dengan lancar dan tidak gugup saat berdiskusi di dalam kelas (A6) suka berbicara, berdiskusi, dan menjelaskan sesuatu panjang lebar (A7). Indikator yang merefleksikan variabel variabel kinestetik adalah lebih mudah memahami apa yang di pelajari ketika menggerakkan anggota badan (K3) Saat presentasi, melakukan dengan gerakan (gerakan tangan/berjalan/serong kiri atau kanan) (K6) menyukai aktivitas di kelas yang membutuhkan pergerakan anggota tubuh (K7).

\section{Discriminant Validity}

Discriminant Validity adalah analisis untuk melihat apakah indikator dapat merefleksikan variabel latennya. Jika nilai crossloading variabel latennya lebih tinggi dari variabel laten lainnya maka dapat dikatakan baik.

Discriminant Validity dapat membandingkan dengan niali square root of average variance extracted (AVE) setiap konstruk. Discriminant Validity yang baik apabila jika nilainya lebih besar dari 0.5 . Berikut nilai AVE dari setiap variabel laten pada Tabel 12.

Tabel 12.

Nilai average variance extracted $(A V E)$

\begin{tabular}{cc}
\hline Variabel & Nilai AVE \\
\hline Visual & 0.701 \\
Auditori & 0.552 \\
Kinestetik & 0.657 \\
Prestasi & 0.673 \\
\hline
\end{tabular}

Berdasarkan Tabel 12 dapat dilihat nilai AVE pada semua variabel laten berada pada nilai di atas 0.5. Maka dapat disimpulkan bahwa nilai AVE semua variabel dinyatakan sudah baik. 


\section{Composite Reliability}

Realibilitas konstruk yang diukur dengan dua kriteria yaitu composite reliability dan cronbach alpha. Konstruk dinyatakan reliable jika nilai composite reliability dan cronbach alpha di atas 0.70 . Berikut merupakan nilai dari composite reliability penelitian ini pada Tabel 13.

Tabel 13.

Nilai composite reliability

\begin{tabular}{lll}
\hline \multicolumn{1}{c}{ Variabel } & Nilai composite reliability & Nilai cronbach alpha \\
\hline Visual & 0.822 & 0.601 \\
Auditori & 0.826 & 0.738 \\
Kinestetik & 0.848 & 0.745 \\
Prestasi & 0.860 & 0.758 \\
\hline
\end{tabular}

Berdasarkan Tabel 13 dapat dilihat bahwa seluruh variabel memiliki nilai composite reliability dan cronbach alpha lebih besar dari 0.70. Maka dapat disimpulkan bahwa semua variabel laten adalah reliabel.

\section{Evaluasi Inner Model}

Pengujian model structural dapat dilakukan dengan melihat nilai $R$-square yang merupakan uji goodness-fit. Nilai tersebut diinterpretasikan bahwa variabilitas konstruk prestasi yang dapat dijelaskan oleh gaya belajar visual, gaya belajar auditori dan gaya belajar kinestetik sebesar $40.8 \%$ sedangkan $59.2 \%$ dijelaskan oleh variabel lain diluar yang diteliti. Uji yang kedua adalah pengujian melalui metode bootsrapping untuk melihat nilai T-statistik dan juga path coefficient yang digunakan untuk melihat nilai asli sampel. Niali T-statistik yang diperoleh digunakan untuk mengukur signifikansi pengaruh antar variabel laten. Hasil bootsrapping dapat dilihat pada Gambar 5.

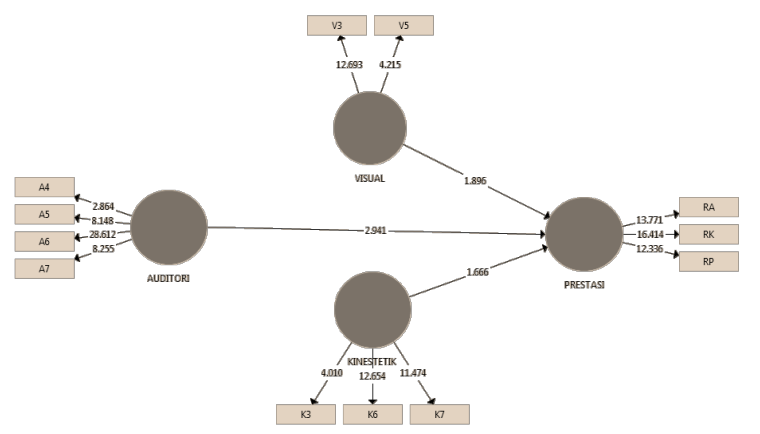

Gambar 5. Model dan perhitungan akhir menggunakan bootstrapping

Berdasarkan Gambar 5 dapat diketahui model perhitungan akhir dengan menggunakan bootstrapping. Uji hipotesis dilakukan untuk melihat T statistik. Jika nilai $\mathrm{T}$ hitung $>\mathrm{T}$ tabel yaitu 2.021 Hipotesis dapat diterima jika nilai T-statistik lebih dari 2.021 (T-statistik
$>2.021$ ) dan sebaliknya. Sampel Original berfugsi untuk melihat sifat hubungan antara variabel laten (positif dan negatif). Berikut merupakan uji hipotesis dapat dilihat pada Tabel 14.

Tabel 14.

Hasil path coefficient

\begin{tabular}{lccc}
\hline \multicolumn{1}{c}{ Jalur Pengaruh } & Sampel Original & T-statistic & Hipotesis \\
\hline Visual> Prestasi & 0.218 & 1.896 & $\begin{array}{c}\text { Tidak } \\
\text { Signifikan }\end{array}$ \\
Auditori>Prestasi & 0.342 & & Signifikan \\
Kinestetik $>$ & 0.219 & 1.6661 & Tidak \\
Prestasi & & & Signifikan \\
\hline
\end{tabular}

Berdasarkan Tabel 14 konstruk gaya belajar visual terhadap prestasi mahasiswa memiliki T-statistik sebesar 1.896; konstruk gaya belajar auditori terhadap prestasi mahasiswa memiliki T-statistik sebesar 2.941; konstruk gaya belajar kinestetik terhadap prestasi mahasiswa memiliki T-statistik sebesar 1.666. Maka dapat disimpulkan bahwa konstruk gaya belajar visual dan gaya belajar kinestetik tidak berpengaruh terhadap prestasi mahasiswa sedangkan konstruk gaya belajar auditori berpengaruh positif dan signifikan terhadap prestasi. Diharapkan dapat menjadi evaluasi pembelajaran dan pengajaran yang tepat untuk diterapkan kepada mahasiswa khususnya yang memiliki IPK $<3.00$ dengan mayoritas memiliki gaya belajar auditori untuk meningkatkan prestasi bidang akademik maupun non akademik.

\section{Implikasi Manajerial}

Berdasarkan hasil analisis deskriptif dan SEM PLS Departemen Manajemen sebaiknya memperbaiki metode pengajaran dan pembelajaran yang sesuai dengan gaya belajar mahasiswa. Terkait dengan hasil gaya belajar, hal tersebut mendorong adanya implikasi manajerial sebagai bahan pertimbangan bagi Departemen Manajemen untuk meningkatkan prestasi mahasiswa. Implikasi manajerial digambarkan dengan diagram alir.

Berdasarkan Gambar 6 pada proses input adalah hasil dari penelitian yaitu gaya belajar auditori yang memengaruhi terhadap prestasi secara signifikan. Prestasi mahasiswa direfleksikan adalah kognitif, afektif, dan psikomotorik. Pada proses perencanaan kegiatan belajar mengajar, saat kuliah berlangsung tim pengajar tentunya harus menjelaskan materi kuliah dengan intonasi atau suara yang keras dan jelas. Metode pembelajaran yang tepat untuk gaya belajar tersebut berupa ceramah, demostrasi, presentasi dan 
lainnya.

Pada proses kegiatan pembelajaran. Departemen Manajemen berperan dalam memberikan fasilitas berupa ruang kelas yang nyaman dan tenang, memastikan fasilitas yang memadai (mic, sound, LCD, lainnya). Hal ini sesuai dengan hasil penelitian yang menunjukkan bahwa gaya belajar auditori sangat peka terhadap suara, sehingga perlu adanya fasilitas yang memadai agar dapat menigkatkan konsentrasi saat perkuliahan berlangsung. Selain itu Departemen Manajemen dapat berperan dalam memfasilitasi mahasiswa untuk meningkatkan kemampuan berbahasa inggris dan asing. Kemampuan berbahasa sangat diperlukan dalam berkomunikasi di era revolusi industri 4.0 saat ini, dimana perusahaan dalam menyaring calon pegawai memerlukan adanya hasil tes Bahasa Inggis. Peningkatan kemampuan berbahasa inggris dapat dilakukan dengan praktik langsung di dalam kelas serta penyediaan fasilitas les TOEFL bagi mahasiswa. Selanjutnya pihak Departemen manajemen perlu adanya evaluasi pengajaran dan pembelajaran dengan cara memperbaiki kurikulum dengan menerapkan metode pembelajaran visualization, auditory, kinesthetic (VAK). Model pembelajaran VAK merupakan gaya belajar yang menggunakan tiga macam sensori dalam menerima informasi yaitu penglihatan, pendengaran, dan gerak. Departemen Manajemen dapat berperan dalam memfasilitasi peningkatan kemampuan pengolahan data berupa Microsoft office/SPSS/SEM/Mini tab dan lainnya. Hal ini sesuai dengan hasil penelitian yang menunjukkan pada variabel prestasi. Peningkatan kemampuan mengolah data dapat dilakukan dengan mengadakan pelatihan, khususnya untuk mahasiswa tingkat akhir dalam proses penyelesaian tugas akhir. Tahap akhir dalam diagram implikasi manajerial adalah output yaitu mendukung misi dari Departemen Manajemen FEM IPB.

Berdasarkan Gambar 6 implikasi manajerial menghasilkan bahan rekomendasi untuk Departemen Manajemen FEM IPB diantaranya adalah fasilitas ruang kelas yang nyaman, fasilitas yang memadai (mic, sound, LCD, lainnya), fasilitas kemampuan bahasa asing, memfasilitasi kemampuan pengolahan data, evaluasi kurikulum dengan menerapkan metode VAK. Selanjutnya rekomendasi bagi tim pengajar adalah menjelaskan dengan intonasi yang jelas, menyesuaikan metode pembelajaran dengan gaya belajar auditori, Exposition - Discovery learning, Group - Individual learning.

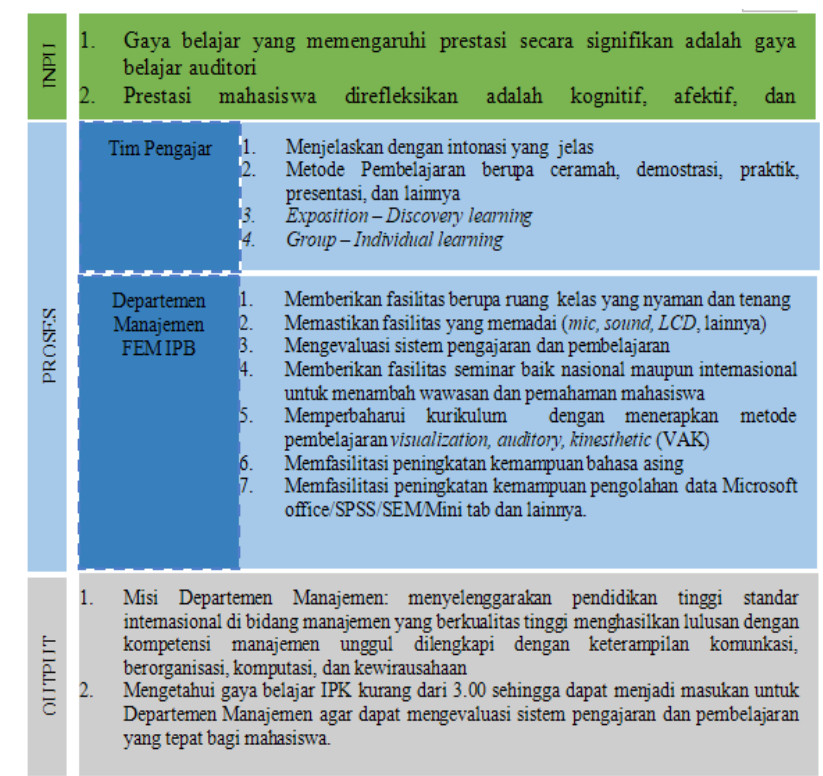

Gambar 6. Model rekomendasi untuk implikasi manajerial pada Departemen Manajemen FEM IPB

\section{PENUTUP}

\section{Kesimpulan}

Berdasarkan hasil penelitian pengaruh gaya belajar terhadap prestasi mahasiswa generasi $\mathrm{Z}$ Departemen Manajemen FEM IPB adalah sebagai berikut (1) mahasiswa generasi Z Departemen Manajemen FEM IPB angkatan 52-55 yang memiliki IPK $<3.00$ didominasi oleh laki-laki sebanyak 40 orang. Berdasarkan usia mahasiswa Departemen Manajemen berusia 19 tahun. Mahasiswa sebanyak 42 orang aktif dalam mengikuti organisasi. Sebanyak 10 orang mahasiswa penerima beasiswa. Jalur penerimaan mahasiswa didominasi melalui jalur SNMPTN yaitu sebanyak 22 orang (2) hasil SEM dengan pendekatan Patrial Least Square (PLS) menunjukan gaya belajar auditori berpengaruh positif dan signifikan terhadap prestasi mahasiswa. Gaya belajar tersebut berpengaruh terhadap variabel prestasi sebesar 40.8 persen sedangkan sisanya dipengaruhi oleh variabel yang tidak di teliti oleh penelitian ini.

\section{Saran}

Saran dari hasil penelitian ini adalah (1) Departemen Manajemen FEM IPB perlu melakukan perbaikan sistem pengajaran dan kurikulum yang lebih aplikatif dengan memperbanyak kegiatan turun lapang, diskusi didalam kelas, dan tugas presentasi. Memanfaatkan teknologi seperti sistem informasi materi perkuliahan melalui LMS, sistem pembelajaran online, pelatihan meningkatkan softskill sehingga mampu mengikuti perkembangan zaman (2) Departemen Manajemen memfasilitasi mahasiswa untuk meningkatkan kemampuan berbahasa Inggris 
dan asing untuk menyiapkan sumberdaya manusia yang berkualitas dan berdaya saing (3) Departemen Manajemen menyelaraskan sistem pembelajaran dengan karakteristik mahasiswa yang memiliki IPK < 3.00 dengan gaya belajar auditori. Evaluasi pengajaran dan pembelajaran kepada seluruh mahasiswa dengan cara memperbaiki kurikulum dengan menerapkan metode pembelajaran visualization, auditory, kinesthetic (VAK). Model pembelajaran VAK merupakan gaya belajar yang menggunakan tiga macam sensori dalam menerima informasi yaitu penglihatan, pendengaran, dan gerak (4) Penelitian selanjutnya disarankan dengan judul analisis pengaruh gaya belajar terhadap prestasi mahasiswa dengan teknik sensus pada mahasiswa departemen manajemen yang memiliki IPK >3.00 Departemen Manajemen FEM IPB

\section{DAFTAR PUSTAKA}

De Porter B, Hernacki M. 2007. Quantum Learning: membiasakan belajar nyaman dan menyenangkan. Cetakan Keduapuluh Lima. Bandung (ID): Kaifa.
Elizabeth TS. 2015. Raising children in digital era. Jakarta

(ID): Bumi Aksara

Ghazali Imam. 2014. Structural Equation Modeling Metode Alternatif dengan Partial Least Square (PLS). Semarang (ID): Badan Penerbit UNDIP. Seemiler C, Grace M. 2016. Generation Z Goes to Collage. New York (NY): Jossey Bass.

Syah M. 2014. Psikologi Belajar. Cetakan Kesembilan Belas. Jakarta (ID): Rajawali Pers.

Moore K, Jones C, dan Frazier RC. 2017. Engineering Education for Generation Z. American Journal of Engineering Education. 8(2).

Sugiyono. 2011. Statistika untuk penelitian. Cetakan Kesembilan Belas. Bandung (ID): CV ALFABETA.

[Kemenristekdikti] Kementerian Riset dan Pendidikan Tinggi Indonesia. 2018. Mempersiapkan SDM Indonesia di Era Industri 4.0. Jakarta (ID).

[Kemenristekdikti] Kementerian Riset dan Pendidikan Tinggi Indonesia. 2017. Pedoman Pemilihan Mahasiswa Berprestasi Program Sarjana. Jakarta (ID). 